\title{
London Poems and History
}

\author{
Tzu Yu Allison Lin \\ Gaziantep University, Gaziantep, Turkey
}

\begin{abstract}
In this article, I read different poems of London through the perspectives of time and the self. The city of London, as a physical space, a world in the globe, is changing through both inner time and outer time. Firstly, in Lord Alfred Tennyson's Cleopatra's Needle, the flow of tide symbolises the passing time, through the long Egyptian history to Tennyson's Victorian London. The Needle has been through different seas and places. The sense of history, a fusion of inner time and outer time, is claimed by the Needle's subjective self, seeing London as a “monster town”. Secondly, Ahren Warner's Greek titled poem is trying to locate the one in London, which cannot be localized, in the trend of globalization, as the gazer observed on the bus. Struggling between the self and the other, inner and outer existences, happiness and being unhappy, W. B. Yeats' from Vacillation comes to show the reader that through reflection and memory, the sense of one's own self can be reinforced and affirmed, while creating one's own personal history. Last but not the least, I read a part from T. S. Eliot's Four Quartets. As the dialectic of light and shadow plays a sense of Beauty, the soul is aware of all fancy things, but only without any meanings. The question of the self and tradition, the poet and the world, somehow, is a timeless one.
\end{abstract}

Keywords: London, self, time, history, tradition

\section{Introduction}

It does not come easily at all, when one tries to define what history is. Sometime it becomes more difficult, when one tries further, to re-discover the meaning of history. Although my initial aim of reading these London poems was to find out something else, magically, the definition of History in these poems somehow comes together as quite a self-fulfillment.

History, in these London poems I chose to read, can be seen as small as a personal event—as Yeats' own birthday reflection and memory, in a way which is totally self-centered and is referring to a completely personal experience. And yet, in these London poems, the readers can see that anything big, such as tradition, time, or the term History with a capitalised "H", must come from something as small as one's own self. The definition of the term History can be varied. As in Tennyson's poem, Cleopatra's Needle, the Needle sees the ups and the downs of the empires. The memory comes to the viewing subject, while standing by the River Thames. The fusion of the past and the present comes, as the Needle concludes to himself- "I was when London was not. / I am here” (Ford, 2012, p. 387).

Tzu Yu Allison Lin, Doctor, Assistant Professor, Department of Foreign Language Education, Faculty of Education, Gaziantep University. 
The history of globalization can be seen in London, when the viewing subject is trying to define, or, to be more precise, to localise the happy outsider in Ahren Warner's poem. History comes to a point, when people come together on the London bus, and go to their own different destinations. History seems to be a joint fate, when in London. It does not matter one is happy or not. In my reading of Eliot's London poem, I somehow feel that the emptiness and the meaningless of the self and of History can be regained through an embracement of tradition and intellectual labour, as Eliot himself implied in his essay.

\section{Subject, Object, and History}

\section{Cleopatra's Needle}

Here, I that stood in On beside the flow

Of sacred Nile, three thousand years ago! —

A Pharaoh, kingliest of his kingly race,

First shaped, and carved, and set me in my place.

A Caesar of a punier dynasty

Thence haled me toward the Mediterranean sea,

Whence your own citizens, for their own renown,

Through strange seas drew me to your monster town.

I have seen the four great empires disappear.

I was when London was not. I am here. (Ford, 2012, p. 387)

In Alfred, Lord Tennyson's Cleopatra's Needle, the sense of history is extremely strong. In the past, Cleopatra's Needle "stood in On beside the flow / Of sacred Nile”. But now (including Tennyson's and our presents), Cleopatra's Needle is standing "beside the flow" of the Thames River in London. In between, there is at least a time difference of "three thousand years". During these years, the subjective "I" of Cleopatra's Needle had travelled and had moved among the seas. Through the changing tide of different seas, history is created in the form of "four great empires", explaining the way in which the Needle was built, and who put it in the place. Now the Needle is in London-a place which is addressed as a "monster town", where everything is possible, especially “darkness” (Agathocleous, 2011, p. 185) as in Charles Dickens's novels. And yet, the Needle's existence expresses something beyond the measurement of time, simply as one can see in the subjective claim of Cleopatra's Needle, “when London was not, I am here”.

For a global city like London, it is really difficult to say what is local and what is not, with all kinds of people, culture and things coming to exist together, in the same place, and yet passing through different time. In Cleopatra's Needle’s eye, the "I” certainly define London as a "monster town”—big, strange, not necessarily beautiful. However, in Ahren Warner's Greek titled poem, the reader can also see again, this kind of time and space complicity and confusion:

Girl with ridiculous earrings why do you bother
to slap the boy we all assume is your boyfriend
and is lolling over that bus seat shouting
it's a London thing. He is obviously a knob
but a happy one and that it seems to me
is the important though not localisable thing. (Ford, 2012, p. 726) 
Many elements mentioned in the poem are "not localisable", for many reasons. For instance, why the girl's earrings are "ridiculous"-compare to what (other objects), to where (other cities and places), to whom (everyone else, or someone specific), to when (her present time, or some other historical time)? Why the girl even bothers to "slap" the boy, as if "shouting" in the bus and "lolling over" the bus seat are totally foreign to Londoners. What if he is not her boyfriend? Can she still slap him? Will the whole thing feel different? Why it is "a London thing”? How can he be "a knob" and yet very happy? Which one is "not localisable"- the knob or the happy one?

The sense of history is also in the inner self, as a kind of personal history, reflection, and memory. Through reflection and memory, the sense of one's "self" can be reinforced and affirmed, while creating one's own personal history. W. B. Yeats' poem shows the reader such a significant moment of solitude and reflection.

\section{Vacillation}

My fiftieth year had come and gone,

I sat, a solitary man,

In a crowded London shop,

An open book and empty cup

On the marble table-top.

While on the shop and street I gazed

My body of a sudden blazed;

And twenty minutes more or less

It seemed, so great my happiness,

That I was blessed and could bless. (Ford, 2012, p. 482)

The poet sat in the crowd, in a London coffee shop, reflecting his past fifty years. On the marble coffee table, there are a book and an empty cup. The cup is empty, showing that he has been there for some time, done some reading and drinking. While he looked around, for about twenty minutes, he felt a great joy, as if his body was on fire, burning, feeling happy, and feeling blessed and was able to give bless to other people.

\section{Poet, Tradition, and the Globe}

Time is a significant issue, in the city of London. In T. S. Eliot's poem, the relation between time and space comes to show the essence of London, in a way which London is a place "in a dim light", expressing a feeling of "lucid stillness" from Four Quartets (from Burnt Norton III).

Here is a place of disaffection

Time before and time after

In a dim light: neither daylight

Investing form with lucid stillness

Turning shadow into transient beauty

With slow rotation suggesting permanence

Nor darkness to purify the soul

Emptying the sensual with deprivation

Cleansing affection from the temporal.

Neither plentitude nor vacancy. Only a flicker

Over the strained time-ridden faces

Distracted from distraction by distraction 
Filled with fancies and empty of meaning

Tumid apathy with no concentration

Men and bits of paper, whirled by the cold wind

That blows before and after time,

Wind in and out of unwholesome lungs

Time before and time after.

Eructation of unhealthy souls

Into the faded air, the torpid

Driven on the wind that sweeps the gloomy hills of London.

Hampstead and Clerkenwell, Campden and Putney,

Highgate, Primrose and Ludgate. Not here

Not here the darkness, in this twittering world.

Descend lower, descend only

Into the world of perpetual solitude,

World not world, but that which is not world,

Internal darkness, deprivation

And destitution of all property,

Desiccation of the world of sense,

Evacuation of the world of fancy,

Inoperancy of the world of spirit;

This is the one way, and the other

Is the same, not in movement

But abstention from movement; while the world moves

In appetency, on its metalled ways

Of time past and time future. (Ford, 2012, pp. 517-518)

The dialectic of light and shadow indicates a kind of "transient beauty". Somehow the temporal signs are on the poets' faces ("men and bits of paper"). They are faces of "time-ridden”, like souls which "nor darkness to purify" - profound and complicated. The status of standstill, as something is "distracted from distraction by distraction / filled with fancies and empty of meaning”. Everything seems to be changing, and yet, to a status of changing same. It does not matter "time before and time after", or "time past and time future", the wind "sweeps the gloomy hills of London / Hampstead and Clerkenwell, Campden and Putney, / Highgate, Primrose and Ludgate". The centre of the soul is solitude and dark, even if the external world is unsettle and "twittering".

Without the self and his or her own identity, history, either personal or non-personal, will be merely like a very dry story-just as an "empty space" (Eagleton, 1994, p. 46), showing an image of "whorelike" "emptiness" (Eagleton, 1994, p. 45)—as the self and the soul are detached, in T. S. Eliot's poem, from "the world of sense", "the world of fancy", and "the world of spirit” (Ford, 2012, pp. 517-518). Although human faces are "time-ridden” (Ford, 2012, p. 517), still, those faces only represent something which are "distracted from distraction by distraction” (Ford, 2012, p. 517), totally meaningless, without any sense of cultural root or centre. Everything is up in the air—no order, "no concentration" (Ford , 2012, p. 517)—just like poets and their papers-blowing. As "the cold wind" (Ford, 2012, p. 517) blows in and out of people's lungs, their "unhealthy souls" (Ford, 2012, p. 517) seem to be fading away, together with the sweeping wind that blows "the gloomy hills of London"-from "Hampstead and Clerkenwell, Campden and Putney", all the way to "Highgate, Primrose and Ludgate” (Ford, 2012, p. 517). 
Through "a feeling" (Eliot, 2006, p. 2320) of having the literary tradition in mind, the poet "has a simultaneous existence" with "his own contemporaneity", as "the historical sense" is somehow a feeling of timelessness, which comes to against the physical movement of the external world-the whole temporal and spatial existence. As Eliot himself stated in his “Tradition and the Individual Talent”, the sense of history is a perception, in a way which the self is in his contemporary, while showing his awareness of the past, the tradition. It is worth it to quote the whole paragraph:

Yet if the only form of tradition, of handing down,
consisted in following the ways of the immediate generation
before us in a blind or timid adherence to its successes,
"tradition" should positively be discouraged. We have seen
many such simple currents soon lost in the sand; and novelty
is better than repetition. Tradition is a matter of much wider
significance. It cannot be inherited, and if you want it you
must obtain it by great labour. It involves, in the first place,
the historical sense, which we may call nearly indispensable
to any one who would continue to be a poet beyond his
twenty-fifth year; and the historical sense involves a
perception, not only of the pastness of the past, but of its
presence; the historical sense compels a man to write not
merely with his own generation in his bones, but with a
feeling that the whole of the literature of Europe from Homer
and within it the whole of the literature of his own country
has a simultaneous existence and composes a simultaneous
order. This historical sense, which is a sense of timeless as
well as of the temporal and of the timeless and of the
temporal together, is what makes a writer traditional. And it
is at the same time what makes a writer most acutely
conscious of his place in time, of his own contemporaneity. (Eliot, 2006, p. 2320)

Again, in this paragraph, one can see many binary oppositions coming together as dialectics, as in Eliot's poem — such as timeless verses the temporal, tradition verses contemporaneity. A poet's historical sense means not only a "perception", but also "a feeling that the whole of the literature of Europe from Homer and within it the whole of the literature of his own country has a simultaneous existence and composes a simultaneous order" (Eliot, 2006, p. 2320). And yet, a poet, together with the tradition (the whole literature of Europe and his own country), there is a "contemporaneity" can be formed, and to be called, as his own. This literature of one's own does not come easily at all. A poet needs to work hard to read through the tradition, not only in a sense of its "pastness", but also with his own perception in his present, Without doing that, all so-called "new" ideas would be like "simple currents", worthless and easy to fade away.

Without tradition, the self and anything which can be called "new”, is easy to be "lost in the sand" (Eliot , 2006, p. 2320). As the wave of time comes, if there is no centre, no tradition, no identity, no root to hold on to, the so-called "present" will not be meaningful. I would suggest that in Eliot's poem, all will be representing nothing but a "whorelike” “emptiness" (Eagleton, 1994, p. 45), because this feeling of emptiness and meaningless comes from a humanity, which is in pain for all kinds of reasons: war, poverty, psychological disorder, and so on, and so forth, as Brunet feels and sees in Jean-Paul Sartre's Iron in the Soul, "a 
machine-gun" has twisted the world, made his head empty, for the very reason that humanity is suffering_-“Suffering humanity_[...] like dogs!” (Sartre, 1963, p. 256).

This kind of humanity, in pain, suffering, could be one of the most shocking awareness of "contemporary emptiness”, as Frank Lentricchia once phrased it in his Modernist Quartet (Lentricchia, 1994, p. 246). The feeling of emptiness can be read as a situation of being lost, as human faces are "time-ridden", "Distracted from distraction by distraction / Filled with fancies and empty of meaning” (Ford, 2012, p. 517). And yet, the feeling of emptiness can also be read as a sign, in a way which the self somehow loses his or her contact with tradition, as the concept of tradition can be interpreted as the representation of history and cultural heritage. Without a literary and a historical point of view, the self will not be able to "remake history on his own terms" (Bann, 1989, p. 103). In other words, the self will need to remake tradition, so that it can be of his own.

\section{Conclusion}

The meaning of life, in London, somehow is a representation of a unity. The dialectic of the opposite poles, such as emptiness and hope, memory, and the present, local and the "not localisable", "time before and time after"- becomes a kind of realization of humanity. Instead of merely looking at "une passante" in a poetic sense of Baudelaire's, as if taking snapshots of each present moment, the London selves are doing something different. The London poems I read in this research show the readers the importance of thinking: either remembering of one's own past, or obtaining the tradition to the contemporary self, or thinking about Londoners in a global context, or looking at the city and being aware of one's own existence-in reading some aspects of London poems, one can start to be sure that "only a redeemed mankind receives the fullness of its past - which is to say, only for a redeemed mankind has its past become citable in all its moments" (Benjamin, 1968, p. 254). The self, and his or her own memory and reflection, are not historically determined or labelled. They are, on the contrary, in a process of writing a history, of London and the globe.

\section{References}

Agathocleous, T. (2011). Urban realism and the cosmopolitan imagination in the nineteenth century: Visible city, invisible world. Cambridge: Cambridge University Press.

Bann, S. (1989). The sense of the past: Image, text, and object in the formation of historical consciousness in nineteenth-century Britain. Veeser, 102-115.

Benjamin, W. (1968). Illuminations: Essays and reflections. (H. Zohn, Trans.). New York: Schocken.

Ford, M. (Ed.). (2012). London: A history in verse. Cambridge, MA: Harvard University Press.

Eagleton, T. (1994). Walter Benjamin or towards a revolutionary criticism. London: Verso.

Eliot, T. S. (2006). Tradition and the individual talent. In S. Greenblatt and M. H. Abrams (Eds.), The Norton anthology of English literature (Vol. 2). New York: W. W. Norton.

Lentricchia, F. (1994). Modernist quartet. Cambridge: Cambridge University Press.

Sartre, J. P. (1963). Iron in the soul. (G. Hopkins, Trans.). Middlesex: Penguin.

Veeser, H. A. (Ed.). (1989). The new historicism. London: Routledge. 